\title{
Glucagon Regulation of Plasma Ketone Body Concentration in Human Diabetes
}

\author{
David S. Schade and R. Phim Eaton \\ From the Department of Medicine, University of New Mexico School of \\ Medicine, Albuquerque, New Mexico 87131
}

\begin{abstract}
A в S T R A C T The present study was designed to test the hypothesis that physiological concentrations of glucagon may increase plasma ketone body concentration when sufficient free fatty acid substrate is available to support hepatic ketogenesis. Physiological elevations of plasma glucagon concentration were produced by a constant infusion of hormone, and increased plasma-free fatty acid availability was produced by simultaneous heparin injection to induce intravascular lipolysis. In the five insulin-dependent diabetic subjects studied, when plasma glucagon concentration remained at the normal basal level of $72 \pm 14 \mathrm{pg} / \mathrm{ml}$ during control saline infusion, the heparin-induced increase in free fatty acid availability resulted in approximately a $20 \%$ increase in plasma ketone body concentration. In contrast, when plasma glucagon concentration was elevated by hormone infusion to the physiological level of $215 \pm 35 \mathrm{pg} / \mathrm{ml}$, the heparin-induced increases in free fatty acid availability resulted in approximately an $80 \%$ increase in plasma ketone body concentration. These results suggest that physiological elevations in plasma glucagon concentration may augment ketonemia in diabetic man when simultaneous elevations in plasma-free fatty acid are present.
\end{abstract}

\section{INTRODUCTION}

Diabetic ketoacidosis is a clinical condition characterized by an elevation in the plasma concentrations of ketone bodies, free fatty acids (FFA), and glucagon (1). As recently reviewed by J. D. McGarry and D. W. Foster (2), in order to attain the excessive concentrations of ketone bodies observed in this clinical state, two physiological conditions must be met: first, adequate free fatty acid substrate must be available to support hepatic ketogenesis, and second, hepatic conversion of free fatty acids to ketone bodies via the $\beta$-oxidation pathway must be

Dr. S. Schade is a Research Associate of the American Diabetes Association.

Received for publication 11 July 1975 and in revised form 19 August 1975. significantly increased. In the present study, we have explored the possibility that the elevated plasma glucagon levels in this clinical state may account for the latter event.

Recent investigations of the pharmacological effects of glucagon in man demonstrate both increased lipolysis and enhanced hepatic ketone body production $(3,4)$, but the plasma levels of hormone attained in these studies exceeded expected endogenously secreted hormone levels (5). The present investigation extends these pharmacological studies to explore the action of physiological elevations in plasma glucagon concentration upon plasma ketone body concentration independent of a lipolytic action. Physiological elevations in plasma glucagon concentration were produced by hormone infusion in both the basal state and during increased FFA availability induced by heparin-activated lipolysis. To exclude a role for changing insulin concentration in these studies, all subjects were insulin-dependent diabetics.

\section{METHODS}

The effect of glucagon infusion and heparin-activated lipolysis upon the plasma concentration of ketone bodies was examined in five healthy insulin-dependent diabetic subjects. This population consisted of two males and three females ranging in age from 22 to $28 \mathrm{yr}$, within $10 \%$ of their ideal body weight according to the Metropolitan Life Insurance Tables (6). Each subject was following a prescribed American Diabetes Association diet and was controlled with one daily 8:00 a.m. injection of U-100 NPH insulin (dosage ranged from 35 to 42 units). Subjects were studied between 7:00 and 8:00 a.m. after a $12 \mathrm{~h}$ overnight fast and $24 \mathrm{~h}$ after their previous therapeutic insulin injection. Four of the five diabetics were in good control, and the fifth (S. G.) was a "brittle" diabetic with ketonuria immediately before her daily insulin injection.

All subjects assumed the supine position for $30 \mathrm{~min}$ before testing and maintained this position throughout the duration of the test. Each antecubital vein was catheterized with a no. 19 scalp vein needle and patency was maintained by constant infusion of normal saline $(1 \mathrm{ml} / \mathrm{min})$ with a Harvard infusion pump (Harvard Apparatus Co., Inc., Millis, Mass.). Blood samples were withdrawn from one arm while infusion of saline or of glucagon in saline was administered into the contralateral arm. 
Two studies were performed on each diabetic subject 1 wk apart. The "control study" consisted of a $50 \mathrm{~min}$ saline infusion $(1 \mathrm{ml} / \mathrm{min})$ with intravenous sodium heparin injection $(5,000 \mathrm{U})$ after a $30 \mathrm{~min}$ basal period to acutely raise the plasma FFA concentration (7). The "glucagon infusion study" consisted of a glucagon infusion $(3.0 \mathrm{ng} / \mathrm{kg}$ per $\mathrm{min}$ ) in place of the saline infusion. $10 \mathrm{ml}$ of each subject's plasma was added to the $500 \mathrm{ml}$ of saline diluent to prevent non-specific adherence of glucagon to the plastic container and tubing. To $500 \mathrm{ml}$ of this "proteinized" saline, sufficient glucagon (Eli Lilly and Co., Indianapolis, Ind.) was added such that infusion of $1.0 \mathrm{ml} / \mathrm{min}$ would deliver $3.0 \mathrm{ng} / \mathrm{kg}$ per min to the subject. Blood samples were obtained at $10 \mathrm{~min}$ intervals over the initial $30 \mathrm{~min}$ base-line period, and after bolus heparin injection at $+2,+5,+10$, +15 , and +20 min.

All blood samples were assayed for $\beta$-hydroxybutyrate, acetoacetate, free fatty acids, and glucose, as previously described (4). Circulating free insulin concentration was as-

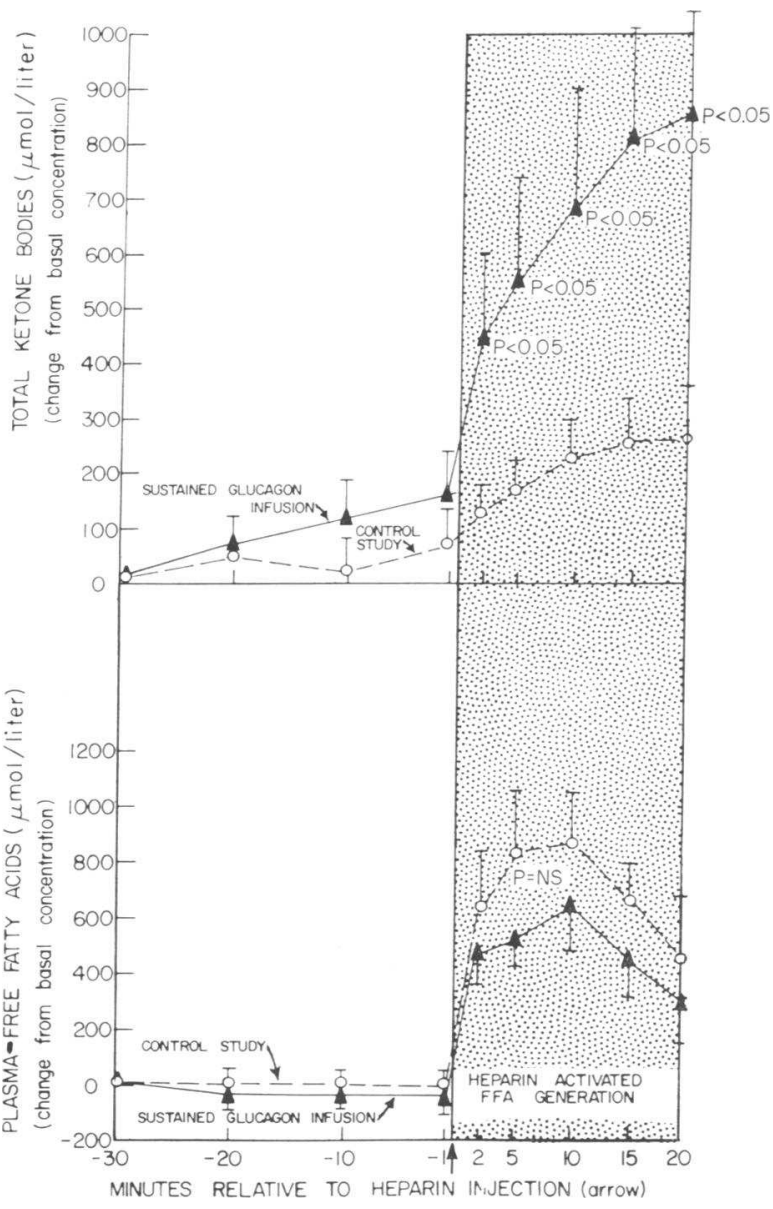

FIGURE 1 Glucagon augmentation of plasma ketone body concentration during basal and augmented free fatty acid availability in diabetic subjects. Change in plasma ketone body concentration (upper panel) and plasma free fatty concentration (lower panel) in the control saline infusion study and sustained glucagon infusion study $(3.0 \mathrm{ng} / \mathrm{kg}$ per $\min )$. Mean $\pm \mathrm{SEM}$ are expressed as change from base-line concentration. sayed as previously reported in insulin-requiring diabetics after endogenous antibody precipitation with polyethylene glycol (8). Glucagon concentration was assayed in plasma as previously described (4) with $30 \mathrm{~K}$ antibody obtained from Dr. Roger Unger, Dallas VA Hospital, Dallas, Tex. 72535. Since each subject was used as his own paired control, Student's $t$ Test for paired samples was employed to evaluate the significance of the difference between sample means (9). Variance of the mean is expressed as the standard error of the mean (SEM).

\section{RESULTS}

\section{Plasma ketone concentration (Fig. 1)}

Control Study-Table I. Total plasma ketone bodies are expressed as the sum of the concentrations of acetoacetate and $\beta$-hydroxybutyrate. In the control saline infusion, no significant $(P>0.05)$ change in plasma ketone body concentration occurred during the basal $30 \mathrm{~min}$ of observation. Within $2 \mathrm{~min}$ after heparin-activated FFA generation, a $20 \%$ increase in plasma ketone body concentration was observed which became maximal by 20 min postinjection $(P<0.05)$. As shown by the mean values of acetoacetate and $\beta$-hydroxybutyrate in Table I, the changes in the concentration of these two substrates closely paralleled each other.

Glucagon infusion (Table I, Fig. 1). In contrast to the control saline infusion, infusion of glucagon during the basal period resulted in a small but nonsignificant increase in plasma ketone body concentration from a mean of $727 \mu \mathrm{mol} /$ liter to $883 \mu \mathrm{mol} /$ liter $(P>0.05)$. After heparin activated FFA generation, an $80 \%$ increase in concentration of ketone bodies was observed, resulting in a mean rise of $706 \mu \mathrm{mol} /$ liter $(P<0.05)$. This glucagon-augmented ketonemia significantly exceeded the rise after heparin in the control saline study at every time of observation $(P<0.05$, Fig. 1$)$, which resulted in a mean rise of $185 \mu \mathrm{mol} / \mathrm{liter}$. Thus, when heparin-activated lipolysis provided increased FFA availability to support hepatic ketogenesis, the infusion of glucagon compared to the infusion of saline resulted in an augmented rise in plasma ketone body concentration.

Plasma free fatty acids (Table II, Fig. 1). Plasma FFA concentration was indistinguishable at all observation times when the saline infusion study was compared to the glucagon infusion study $(P>0.05$, Fig. 1). In spite of the lipolytic effects of glucagon at pharmacological concentrations, no increase in plasma FFA was observed at the physiological levels of plasma glucagon attained in our study (Table II). After bolus heparin injection, an immediate increase in plasma FFA was observed in both studies, obtained a maximal concentration of $1,796 \pm 279 \mu \mathrm{mol} /$ liter by $+10 \mathrm{~min}$ postinjection in the saline control study and a comparable level of $1.536 \pm 203 \mu \mathrm{mol} /$ liter in the glucagon infusion study $(P>0.05)$. Thus, based on both the absolute 
TABLE I

Plasma Concentration of Total Ketone Bodies in Five Diabetic Subjects during Saline Control and Glucagon Infusion Studies

\begin{tabular}{|c|c|c|c|c|c|c|c|c|c|}
\hline & \multicolumn{9}{|c|}{ Heparin injection } \\
\hline & \multicolumn{4}{|c|}{ Minutes } & \multicolumn{5}{|c|}{ FFA generation, minutes } \\
\hline & -30 & -20 & -10 & -1 & +2 & +5 & +10 & +15 & +20 \\
\hline & & & & & 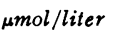 & & & & \\
\hline \multicolumn{10}{|l|}{ Saline control } \\
\hline M. C. & 445 & 447 & 445 & 445 & 710 & 730 & 690 & 735 & 842 \\
\hline J. D. & 500 & 494 & 502 & 498 & 564 & 820 & 1,035 & 935 & 800 \\
\hline D. D. & 309 & 314 & 297 & 308 & 370 & 468 & 524 & 504 & 537 \\
\hline S. G. & 3,035 & 3,261 & 3,057 & 3,343 & 3,256 & 3,091 & 3,122 & 3,200 & 3,204 \\
\hline K. K. & 468 & 514 & 581 & 535 & 529 & 520 & 555 & 628 & 673 \\
\hline Mean AcAc & 229 & 239 & 276 & 259 & 310 & 358 & 338 & 333 & 351 \\
\hline Mean BOH & 722 & 766 & 700 & 767 & 776 & 767 & 847 & 867 & 861 \\
\hline Mean total KB & 951 & 1,006 & 979 & 1,026 & 1,086 & 1,126 & 1,185 & 1,200 & 1,211 \\
\hline \multicolumn{10}{|l|}{ Glucagon infusion } \\
\hline M. C. & 592 & 648 & 708 & 755 & 1,360 & 1,490 & 1,630 & 1,780 & 1,690 \\
\hline J. D. & 383 & 447 & 506 & 567 & 925 & 1,090 & 1,240 & 1,370 & 1,300 \\
\hline D. D. & 334 & 377 & 392 & 387 & 690 & 657 & 692 & 680 & 666 \\
\hline S. G. & 1,786 & 2,050 & 2,145 & 2,230 & 2,460 & 2,680 & 2,910 & 3,130 & 3,286 \\
\hline K. K. & 540 & 473 & 442 & 478 & 463 & 484 & 561 & 725 & 920 \\
\hline Mean AcAc & 202 & 256 & 266 & 290 & $455^{*}$ & $485^{*}$ & $535^{*}$ & $578^{*}$ & $581^{*}$ \\
\hline Mean $\mathrm{BOH}$ & 527 & 543 & 578 & 593 & 725 & 795 & 871 & $959^{*}$ & $988^{*}$ \\
\hline Mean total KB & 727 & 799 & 844 & 883 & $1,180^{*}$ & $1,280^{*}$ & $1,407^{*}$ & $1,537^{*}$ & $1,589^{*}$ \\
\hline
\end{tabular}

* Signifies that the change in concentration from base line $(-30 \mathrm{~min})$ in the glucagon infusion study is statistically greater than the change in concentration from base line in the control study $(P<0.05)$.

concentration of plasma free fatty acids (Table II) and the rise in plasma FFA concentration above basal concentration (Fig. 1), FFA availability for ketogenesis was not different in the two studies.

Plasma glucagon concentration (Table II). In the saline control study, mean basal plasma glucagon concentration was $74 \pm 24 \mathrm{pg} / \mathrm{ml}$ and no significant change in concentration was observed at any time of observation during the basal period or after heparin injection (Table II). After the initiation of hormone infusion, plasma glucagon concentration promptly rose from a base line of $63 \pm 20 \mathrm{pg} / \mathrm{ml}$, attaining a plasma level of approximately $215 \mathrm{pg} / \mathrm{ml}$ (Table II). Thus, glucagon infusion produced peripheral plasma glucagon concentrations which were several times greater than the basal value, but still below the pathophysiological elevations reported in ketoacidosis (5).

Plasma insulin concentration (Table II). Plasma insulin concentration, assayed after polyethylene glycol antibody precipitation, was within the reported range for 12-h fasting diabetic subjects assayed by this method (8). During both control and glucagon infusion studies, no significant change in insulin concentration was observed $(P>0.05)$.
Plasma glucose concentration (Table II). Mean basal plasma glucose concentration exceeded $200 \mathrm{mg} / \mathrm{dl}$ in both the control and glucagon infusion experiments reflecting the fact that $24 \mathrm{~h}$ had elapsed since the previous therapeutic insulin injection. In the control saline study, no change in glucose concentration occurred, although after heparin injection, a nonsignificant decline in plasma glucose concentration was observed $(P>0.05)$. In the glucagon infusion study, a progressive rise in glucose concentration to a mean of $227 \mathrm{mg} / 100 \mathrm{ml}$ was observed, which attained statistical significance after $30 \mathrm{~min}$ of infusion $(P<0.05)$. This elevation in plasma glucose concentration was sustained throughout the postheparin injection period (Table II).

\section{DISCUSSION}

This study was designed to examine the effect of physiological elevations of glucagon upon the plasma concentrations of ketone bodies in diabetic man. Our results demonstrate that at physiological levels, in the range of $215 \mathrm{pg} / \mathrm{ml}$, glucagon can induce an increase in plasma ketone body concentration when sufficient free fatty acid substrate is available to support hepatic ketogenesis. 
TABLE II

Plasma Concentration of Free Fatty Acids, Glucose, Glucagon, and Insulin in Five Diabetic Subjects during Control and Glucagon Infusion Studies (Mean $\pm S E M$ )

\begin{tabular}{|c|c|c|c|c|c|c|c|c|c|}
\hline & \multicolumn{9}{|c|}{ Heparin injection } \\
\hline & \multicolumn{4}{|c|}{ Minutes } & \multicolumn{5}{|c|}{ FFA generation, minutes } \\
\hline & -30 & -20 & -10 & -1 & +2 & +5 & +10 & +15 & +20 \\
\hline \multicolumn{10}{|l|}{ Saline control } \\
\hline Free fatty acid, $\mu$ mol/liter & $\begin{array}{r}913 \\
\pm 178\end{array}$ & $\begin{array}{r}916 \\
\pm 176\end{array}$ & $\begin{array}{r}916 \\
\pm 178\end{array}$ & $\begin{array}{r}918 \\
\pm 178\end{array}$ & $\begin{array}{r}1554 \\
\pm 255\end{array}$ & $\begin{array}{r}1756 \\
\pm 306\end{array}$ & $\begin{array}{l}1796 \\
\pm 279\end{array}$ & $\begin{array}{c}1588 \\
\pm 224\end{array}$ & $\begin{array}{r}1366 \\
\pm 170\end{array}$ \\
\hline Glucose, $m g / d l$ & $\begin{array}{r}283 \\
\pm 55\end{array}$ & $\begin{array}{r}278 \\
\pm 55\end{array}$ & $\begin{array}{r}275 \\
\pm 47\end{array}$ & $\begin{array}{r}269 \\
\pm 47\end{array}$ & $\begin{array}{r}265 \\
\pm 48\end{array}$ & $\begin{array}{r}264 \\
\pm 50\end{array}$ & $\begin{array}{r}260 \\
\pm 48\end{array}$ & $\begin{array}{r}255 \\
\pm 47\end{array}$ & $\begin{array}{r}245 \\
\pm 44\end{array}$ \\
\hline Glucagon, $p g / m l$ & $\begin{array}{r}74 \\
\pm 24\end{array}$ & $\begin{array}{r}68 \\
\pm 17\end{array}$ & $\begin{array}{r}62 \\
\pm 15\end{array}$ & $\begin{array}{r}64 \\
\pm 16\end{array}$ & $\begin{array}{r}81 \\
\pm 31\end{array}$ & $\begin{array}{r}103 \\
\pm 49\end{array}$ & $\begin{array}{r}61 \\
\pm 16\end{array}$ & $\begin{array}{r}56 \\
\pm 16\end{array}$ & $\begin{array}{r}60 \\
\pm 18\end{array}$ \\
\hline Insulin, $\mu U / m l$ & $\begin{array}{r}22 \\
\pm 4\end{array}$ & $\begin{array}{r}20 \\
\pm 4\end{array}$ & $\begin{array}{r}20 \\
\pm 4\end{array}$ & $\begin{array}{r}20 \\
\pm 4\end{array}$ & $\begin{array}{r}20 \\
\pm 4\end{array}$ & $\begin{array}{r}22 \\
\pm 4\end{array}$ & $\begin{array}{r}22 \\
\pm 4\end{array}$ & $\begin{array}{r}22 \\
\pm 4\end{array}$ & $\begin{array}{r}22 \\
\pm 4\end{array}$ \\
\hline \multicolumn{10}{|l|}{ Glucagon infusion } \\
\hline Free fatty acid, $\mu \mathrm{mol} / \mathrm{liter}$ & $\begin{array}{r}911 \\
\pm 99\end{array}$ & $\begin{array}{r}903 \\
\pm 95\end{array}$ & $\begin{array}{r}885 \\
\pm 95\end{array}$ & $\begin{array}{r}861 \\
\pm 130\end{array}$ & $\begin{array}{r}1390 \\
\pm 130\end{array}$ & $\begin{array}{r}1432 \\
\pm 132\end{array}$ & $\begin{array}{r}1536 \\
\pm 203\end{array}$ & $\begin{array}{r}1372 \\
\pm 199\end{array}$ & $\begin{array}{r}1205 \\
\pm 163\end{array}$ \\
\hline Glucose, $m g / d l$ & $\begin{array}{r}201 \\
\pm 54\end{array}$ & $\begin{array}{c}211^{*} \\
\pm 51\end{array}$ & $\begin{array}{l}209^{*} \\
\pm 46\end{array}$ & $\begin{array}{l}220^{*} \\
\pm 51\end{array}$ & $\begin{array}{l}217^{*} \\
\pm 50\end{array}$ & $\begin{array}{l}222^{*} \\
\pm 49\end{array}$ & $\begin{array}{l}226^{*} \\
\pm 52\end{array}$ & $\begin{array}{l}226^{*} \\
\pm 51\end{array}$ & $\begin{array}{c}227^{*} \\
\pm 50\end{array}$ \\
\hline Glucagon, $p g / m l$ & $\begin{array}{r}63 \\
\pm 20\end{array}$ & $\begin{array}{c}149^{*} \\
\pm 51\end{array}$ & $\begin{array}{c}233^{*} \\
\pm 45\end{array}$ & $\begin{array}{c}170^{*} \\
\pm 32\end{array}$ & $\begin{array}{c}202^{*} \\
\pm 27\end{array}$ & $\begin{array}{l}271^{*} \\
\pm 47\end{array}$ & $\begin{array}{l}252^{*} \\
\pm 49\end{array}$ & $\begin{array}{l}215^{*} \\
\pm 31\end{array}$ & $\begin{array}{c}202^{*} \\
\pm 28\end{array}$ \\
\hline Insulin, $\mu U / m l$ & $\begin{array}{r}24 \\
\pm 6\end{array}$ & $\begin{array}{r}24 \\
\pm 4\end{array}$ & $\begin{array}{r}26 \\
\pm 6\end{array}$ & $\begin{array}{r}26 \\
\pm 6\end{array}$ & $\begin{array}{r}24 \\
\pm 4\end{array}$ & $\begin{array}{r}24 \\
\pm 6\end{array}$ & $\begin{array}{r}24 \\
\pm 6\end{array}$ & $\begin{array}{r}26 \\
\pm 6\end{array}$ & $\begin{array}{r}22 \\
\pm 4\end{array}$ \\
\hline
\end{tabular}

* Signifies that the change in concentration from base line $(-30 \mathrm{~min})$ in the glucagon infusion study is statistically greater than the change in concentration from base line in the control study $(P<0.05)$.

Thus, this action of physiological elevations in glucagon concentration to enhance FFA conversion to ketones provides a hormonal mechanism contributing to the development of ketosis in diabetic ketoacidosis, a state characterized by elevated plasma glucagon concentration in the range of $230-2,000 \mathrm{pg} / \mathrm{ml}$ (5) and increased FFA availability (1).

The ketogenic effect of glucagon infusion in diabetic man has previously only been demonstrated at pharmacological dosages with resulting plasma levels of glucagon in excess of $1,000 \mathrm{pg} / \mathrm{ml}(3,4)$. However, at pharmacological concentrations of glucagon, lipolysis is also stimulated by this hormone. Since elevations of plasma FFA concentrations alone result in increased hepatic ketogenesis (10), interpretations of a direct ketogenic effect of glucagon apart from its lipolytic effect have been difficult. At the low dosage of glucagon utilized in our study, glucagon infusion did not increase plasma FFA concentration. Thus, the ketogenic effect of glucagon cannot be attributed to any lipolytic effect of this hormone.

The mechanism by which glucagon induces an increase in plasma ketone bodies is not resolved by this study. Glucagon may augment plasma ketone bodies by increasing production and/or inhibiting utilization. However, no published data are available describing the peripheral effect of glucagon on ketone body utilization in human diabetes. In mammals, the liver is virtually the sole source of net ketone body production (11). In 1969, M. Heimberg et al. utilizing in vitro liver perfusion experiments demonstrated that glucagon progressively augmented hepatic ketone body production with progressive increases in perfusate FFA concentration (10). More recently, J. D. McGarry et al. (12) demonstrated that glucagon administered in vivo to the rat converted a "nonketotic" liver to a "ketotic" liver when perfused with adequate concentrations of free fatty acid substrate. In man, the net effects of glucagon on hepatic ketone production are less well defined. In vivo studies utilizing hepatic catheterization in diabetic man demonstrated that a glucagon infusion producing plasma hormone levels of approximately $4,000 \mathrm{pg} / \mathrm{ml}$ resulted in both increased lipolysis and increased hepatic ketone production (3). In these studies, the authors were unable to determine whether the augmented hepatic ketone produc- 
tion was a direct effect of glucagon or an indirect effect resulting from the lipolytic activity of the hormone.

Further evidence for a physiological role for glucagon in ketone regulation has been provided by observations of the effect of acute suppression of endogenous glucagon secretion in diabetic man. As recently reported (13), the reduction in plasma glucagon resulting from somatostatin infusion is associated with a parallel reduction in the rise in plasma ketone concentration during insulin withdrawal. In addition, other studies have demonstrated that the severity of ketoacidosis is closely correlated with the concentration of plasma glucagon $(1,14)$. Thus, our data complement and extend previous investigations suggesting a role for glucagon in physiological regulation of human diabetic ketonemia.

\section{ACKNOWLEDGMENTS}

This study was done with the technical assistance of Evelyn Jensen MT (ASCP) and Jack Sivinski.

This investigation was supported by the American Diabetes Association Grant and by the KROC Foundation.

\section{REFERENCES}

1. Gerich, J. E., E. Tsalikian, M. Lorenzi, J. H. Karam, and D. M. Bier. 1975. Plasra glucagon and alanine responses to acute insulin deficiency in man. J. Clin. Endocrinol. Metab. 40: 526-529.

2. McGarry, J. D., and D. W. Foster. 1972. Regulation of ketogenesis and clinical aspects of the ketotic state. Metab. (Clin. Exp.). 21: 471-489.

3. Liljenquist, J. E., J. D. Bomboy, S. B. Lewis, B. C. Sinclair-Smith, P. W. Felts, W. W. Lacy, O. B. Crofford, and G. W. Liddle. 1974. Effects of glucagon on lipolysis and ketogenesis in normal and diabetic men. J. Clin. Invest. 53: 190-197.

4. Schade, D. S., and R. P. Eaton. 1975. Modulation of fatty acid metabolism by glucagon in man. I. Effects in normal subjects. Diabetes. 24: 502-509.

5. Unger, R. H., E. Aguilar-Parada, W. A. Müller, and A. M. Eisentraut. 1970. Studies of pancreatic alpha cell function in normal and diabetic subjects. J. Clin. Invest. 49: 837-848.

6. Society of Actuaries. 1959. Build and Blood Pressure Study. Vol. I and II. Society of Actuaries, Chicago, Ill.

7. Gerich, J. E., M. Langlois, V. Schneider, J. H. Karam, and C. Noacco. 1974. Effects of alterations of plasma free fatty acid levels on pancreatic glucagon secretion in man. J. Clin. Invest. 53: 1284-1289.

8. Nakagawa, S., H. Nakayama, T. Sasaki, K. Yoshino, Y. Y. Yu, K. Shinozaki, S. Aoki, and K. Mashimo. 1973. A simple method for the determination of serum free insulin levels in insulin-treated patients. Diabetes. 22: $590-600$.

9. Bahn, A. K. 1972. Basic Medical Statistics. Grune and Stratton, New York. 1st edition. 144-149.

10. Heimberg, M., I. Weinstein, and M. Kohout. 1969. The effects of glucagon, dibutyryl cyclic adenosine $3^{\prime}, 5^{\prime}-$ monophosphate, and concentration of free fatty acid on hepatic lipid metabolism. J. Biol. Chem. 244: 5131-5139.

11. Owen, O. E., P. Felig, A. P. Morgan, J. Wahren, and G. F. Cahill, Jr. 1969. Liver and kidney metabolism during prolonged starvation. J. Clin. Invest. 48: 574 583.

12. McGarry, J. D., P. H. Wright, and D. W. Foster. 1975. Hormonal control of ketogenesis. Rapid activation of hepatic ketogenic capacity in fed rats by anti-insulin serum and glucagon. J. Clin. Invest. 55: 1202-1209.

13. Gerich, J. E., M. Lorenzi, D. M. Bier, V. Schneider, E. Tsalikian, J. H. Karam, and P. H. Forsham. 1975. Prevention of human diabetic ketoacidosis by somatostatin. Evidence for an essential role of glucagon. $N$. Engl. J. Med. 292: 985-989.

14. Alberti, K. G., N. J. Christensen, J. Iverson, and H. Ørskov. 1975. Role of glucagon and other hormones in development of diabetic ketoacidosis. Lancet. I: 13071311. 